\title{
Gender Differences In The Fear Of Crime Victimization And Precautionary Behaviours
}

\author{
Taskeen Mansoor \\ $\mathbf{8}$ \\ Rukhsana Hasan \\ Department of Gender Studies \\ Fatima Jinnah Women University Rawalpindi
}

\begin{abstract}
This quantitative study was conducted to explore the gender differences in the fear of crime victimization and associated precautionary behaviours. A questionnaire was designed and administered on 180 students of public and private universities in Islamabad and Rawalpindi. Data analyzed in SPSS showed a significant difference in the responses of males and females where females were more worried and felt more unsafe about being a victim of a crime than males. More females observed precautionary behaviours to avoid being a victim of a crime in relation to the males. The females were fearful of crime related to use of public transport, sexual and gender based attack whereas males feared verbal abuse by strangers or acquaintances. It was discussed that females, being members of a marginalized and vulnerable group, may consider themselves as potential victims to crimes, and therefore exhibit a high fear of crime along with higher incidence of precautionary behaviour. Furthermore, in the patriarchal structure of the Pakistani society, the socio-cultural norms and traditional gender role socialization teach the boys to be dominant, risk-takers and fearless and the girls to be submissive, risk avoiding and fearful which tends to restrict the mobility and freedom of females.
\end{abstract}

Keywords: Fear of Crime, Precautionary Behaviours, Gender Differences

$$
\begin{aligned}
& \text { تثخص }
\end{aligned}
$$

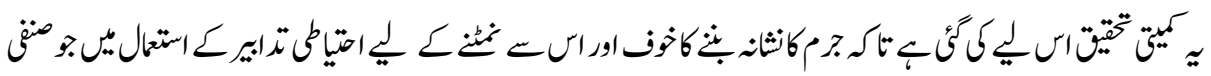

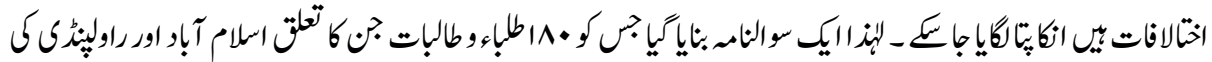

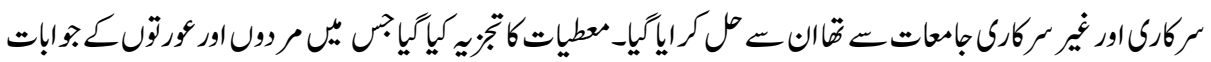

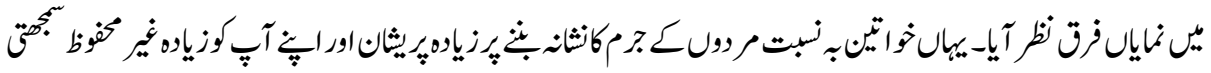

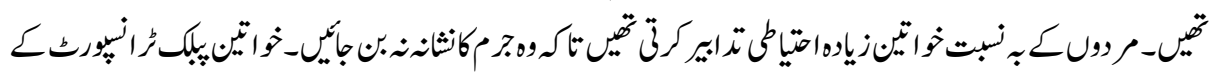

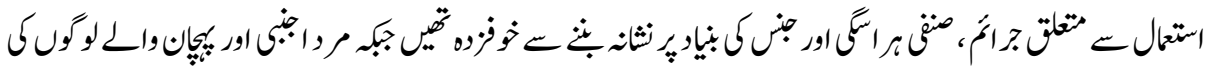

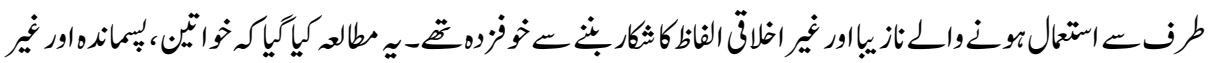

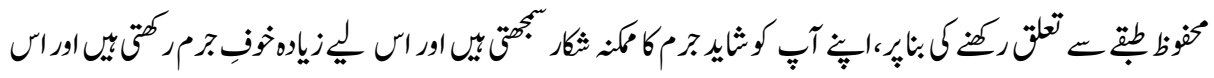




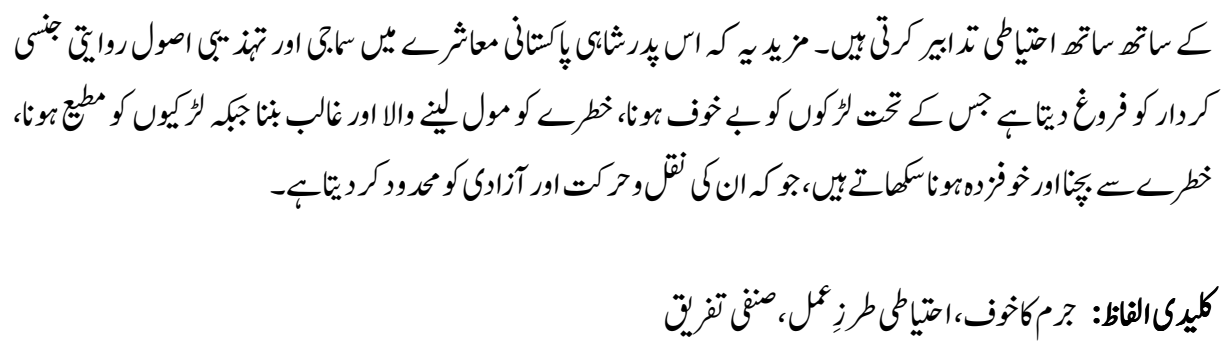

\section{Introduction}

There has been a lot of research in the West related to fear of crime and perceived risk of victimization along with the precautionary behaviours demonstrated by the general population and specifically college/university students. Actual victimization statistics cannot predict the fear of crime. In the case of a developing country like Pakistan, factors like the political instability, increasing mistrust and doubts among the population, gender discrimination in the strong patriarchal structure of society, bomb blasts and suicide attacks along with extensive media coverage of horrific events may tend to increase the fear of crime in the society. If a person feels vulnerable as part of a marginalized group then they will fear crime. This fear may lead to a change in the approach to life for these individuals and daily routine activities may also be affected due to perceived threats of crime.

Researchers and investigators have not reached a consensus on the definition of 'fear of crime'. According to many psychologists, fear is a vital response to physical and emotional danger. According to the Oxford English Dictionary (June, 2013), crime is defined as "an action or omission which constitutes an offence and is punishable by law". In Pakistan, there are some behaviours that were recently acknowledged as criminal offences like sexual harassment and domestic violence. However, the recognition of marital rape and verbal abuse as crimes has not yet been challenged or might not be clearly defined by the law. This study, therefore, does not use the formal documented legal definition of crime instead it employs the sociological perspective of crime where, apart from the individual committing the crime, the social, cultural and political context is also seen as part of the problem.

According to Sur (2012:97), crime is defined as "the power to harm others" which can be associated with inequality with respect to social class and gender. The power dynamics involved in the structure of the society create a system where some people have the power to dominate others and harm them. The individuals affected by a crime are victims who experience the "harms of reduction" and "harms of repression". "Harms of reduction refer to situations when an offended party experiences some immediate loss or injury because of the action of others. Harms of repression refer to situations when power is used to restrict future potential human aspirations or desired standing." (Sur, 2012:97) 
This study uses a broad definition of fear of crime in which there is emotion of stress, apprehension, fright or uneasiness linked to a specific situation, location or object of terror. Sur (2012) uses Rader's (2004) three dimensional concept of fear of crime involving an emotive (fear), cognitive (perceived risk) and behavioural (constrained behaviours) component. Although these elements are not dependent on one another but they are part of a complex relationship. Cognition is being aware of your surroundings and making an estimation of a possibility of victimization whereas emotions are individuals' feelings towards crime. Behavioural aspect is the action that arises out of the fear of crime.

Gender has been found to be one of the most consistent and strong predictors of fear of crime. According to Chan and Rigakos (2002), men and women have to face different types of crimes and therefore differ in their perception of risk and assessment of precautionary measures. Many researches Truman (2007) May, Herbert, Cline \& Nellis (2011) have stated that females are more fearful of crimes relative to men although there are high rates of men being a victim of a crime than women. This disproportional high fear among women is termed by many researchers Smith \& Torstensson (1997) Hale (1996) as the "gender-fear paradox". It may be the case that women do not report the crimes and hence remain hidden victims especially in cases of sexual assaults or domestic violence and being exposed to a crime once; they may fear future potential victimization.

The gender role socialization also contributes to the risk of problems in the adult life of children. The power-control theory proposed by Hagan, J., Simpson, J., \& Gillis, A. R. (1987) shows that there is a relationship between the level of authority of the parents and the resulting behaviour of the children where the children reproduce the gender roles learnt in their family setting. According to the power-control theory, in a conventional family setup (like in Pakistani societies) where the father is dominant, "the boys learn to be assertive, risk-taking and fearless whereas the girls learn to be submissive, risk avoiding, and fearful" (Grasmick, Hagan, Blackwell \& Arneklev, 1996).

Women are more fearful of being victims of crimes when travelling at night than men Hille (1999) Literature shows that prime crime locations include the paths leading to a bus stop, the waiting area and public transport itself and the females may have to deal with the stares of the public at the bus stop and then suffer the overcrowded or cramped conditions in the bus at peak times which makes them feel unsafe (Syam, Reeves \& Khan, 2011).

The media also influences the decisions of the individuals as the images shown project women as submissive, where she is seen as a "damsel in distress" (Zhou, et. al. 2011; White, 1986). The phrase indicates that the damsel is a young unmarried girl who is helpless and unable to save herself in danger. The maiden lacks the survival instincts or real world experience to battle the crime and requires a hero to achieve her rescue. This concept socializes women to "avoid the streets, stay inside, avoid strangers, dress 
properly" Madriz (1997). The females tend to seek external help for fear or problem whereas the aggression of men makes them dominant and less vulnerable to victimization.

Human beings judge their surroundings according to their perception, preconceived notions and socialization thus "As sentient and symbolic beings, however, humans have the ability to anticipate or contemplate events that lie in the future or are not immediately apparent" (Warr, 2000:454). Crime generates fear which leads to a cautious attitude to avoid the possibility of being harmed from the crime. It involves taking precautionary measures to stay safe, potentially causing changes in lifestyle, stress, and additional fear for self or others. "Risk management practices are used when one finds oneself in a potentially dangerous situation and/or location and takes precautionary measures to be a less suitable target for victimization" Scott (2003:205). The pro-active measures taken by individuals, especially women can take many forms. The responses may be "acquiescent, submissive and even passive to us: locking themselves inside their homes, avoiding certain streets and activities, most women have to spend a great amount of energy, time and economic resources to shield themselves from criminal victimization and to minimize their fears" (Madriz, 1997).

Fear is a relative measure and different people may have different perspectives about possible victimization. Women and children or minority groups in a society are most vulnerable to a crime because they belong to marginalized groups and therefore may exhibit higher level of fear associated with crime as projected from the statement "Just being a woman makes you more afraid of things" (Hilinski, Neeson, Andrew, 2011:119). A woman is entrenched in her physicality and gender based violence or attacks degrade, oppress and exploit women therefore they tend to be submissive.

If fear of crime among women especially is as big a social problem as research implies, then researchers who hope to make a difference have an obligation to translate their findings into meaningful recommendations according to the social structure of the society and political context that actually could be used by the policymakers and practitioners (Renzetti, Miller \& Gover, 2012). This study will ask questions related to how safe or worried girls and boys feel in certain situations. The focus will be to identify any patterns of similarity or differences between the girls and boys in their fear of crime and in the approach to deal with it.

\section{Research Methodology}

There are many factors responsible for creating a sense of fear, especially in the Pakistani society where a lack of effective laws along with strong cultural norms create a sense of fear among the general population. This study explores the gender differences in the perception of fear of crime and the precautionary behaviours, if any, that accompany the fear. 


\section{Objectives}

1. To explore the perception of students regarding their fear and safety concerns with respect to different types of crime

2. To determine the gender differences in the fear of crime and safety level of different types of crimes

3. To determine what precautionary measures are taken by respective genders to avoid being a victim of a crime

4. To explore the intensity of fear of crime from strangers as compared to acquaintances

\section{Hypotheses}

1. The female students will express a greater fear of crime.

2. The female students will be more likely to engage in precautionary behaviors.

3. The male and female students will be fearful of different types of crimes

4. The male and female students will adopt different types of precautionary behaviours

\section{Variables}

Dependent variables: fear of crime, precautionary behaviour

Independent: age, gender, education level, university type, university location

\section{Operational Definitions}

Fear: a feeling in anticipation of a possible emotional or physical danger due to environmental stimuli.

Crime: "Power to harm others" Sur (2012) Physical, verbal or sexual assault, stalking and harassment.

Fear of crime: a feeling that one has a probability of being a victim of a crime as opposed to actually witnessing the crime.

Precautionary behaviour: A proactive technique used as a response/reaction to a perceived risk of being a victim of a crime.

\section{Research design}

It was a quantitative study based on questionnaires. The research was carried out in two phases; a try out and a main study. 


\section{Instrument}

For the collection of data in this quantitative research, an understandable easy-worded English questionnaire based on 37 simple questions was prepared. For some questions, examples and definitions of terms were also given to elaborate the question. There was a mix of questions with accompanying scales to answer from which had four specific themes.

\section{Try Out}

A questionnaire was designed and pre-tested on a sample of 20 students (10 males and 10 females) from Islamic International University Islamabad. Data was entered into SPSS to check for reliability ( 0.92 for Section A (worry level), 0.83 for Section B (safety level) and $\mathrm{C}$ (precautionary behaviour))

\section{Sample}

The sample size comprised of 180 students. The range of ages in the sample was between 18-23 which included Bachelors and Masters Students who were day-scholars and availed the facility of public or university transport. With the help of the non-probability 'purposive and convenience' sampling technique, 90 boys and 90 girls were made part of the sample. 30 students comprising of 15 males and 15 females were selected from each university.

\section{Analysis}

Data was analyzed using quantitative methods. By using SPSS, different bivariate analysis tests like Chi square, Independent samples test and Cross tabs were run on the data to get results.

\section{Results}

Table: 1

Intensity of fear of crime committed by stranger and acquaintance (One-Sample Test)

\begin{tabular}{|c|c|c|c|c|}
\hline & $\mathbf{t}$ & Df & $\begin{array}{c}\text { Mean } \\
\text { Difference }\end{array}$ & Sig. (2-tailed) \\
\hline Stranger & 48.646 & 179 & 8.88889 & .000 \\
\hline acquaintance & 38.843 & 179 & 9.18333 & .000 \\
\hline
\end{tabular}


In the above table, the significance value is $0.000<0.05$ which shows that there is a significant difference in the fear of crime committed by stranger and acquaintance. The mean difference for "acquaintance" is 9.2 ; greater than that of "stranger" which is 8.9 indicating that the respondents are more fearful about being a victim of crime committed by acquaintance than for a crime committed by a stranger.

The crosstabs calculation for the values of selected item responses are shown below in the tables where $\mathrm{p}<0.05$ showing the results are statistically significant.

Table: 2

Worry level

\begin{tabular}{|l|l|c|c|c|}
\hline \multicolumn{2}{|c|}{} & $\begin{array}{c}\text { Very } \\
\text { Worried }\end{array}$ & $\begin{array}{c}\text { Little } \\
\text { worried }\end{array}$ & $\begin{array}{c}\text { Not at all } \\
\text { worried }\end{array}$ \\
\hline \multirow{2}{*}{$\begin{array}{l}\text { 1. How worried are you being } \\
\text { a victim of verbal abuse and } \\
\text { insults by a stranger? }\end{array}$} & Males & $24.4 \%$ & $52.2 \%$ & $23.3 \%$ \\
\cline { 2 - 5 } & Females & $23.3 \%$ & $71.1 \%$ & $5.6 \%$ \\
\cline { 2 - 5 } $\begin{array}{l}\text { 2. How worried are you being } \\
\text { a victim of verbal abuse and } \\
\text { insults by someone you know? }\end{array}$ & Motal & $23.9 \%$ & $61.7 \%$ & $14.4 \%$ \\
\cline { 2 - 5 } & Memales & $40.0 \%$ & $31.1 \%$ & $28.9 \%$ \\
\hline \multirow{2}{*}{$\begin{array}{l}\text { 3. How worried are you being } \\
\text { a victim of an attack on you } \\
\text { based on your gender? }\end{array}$} & Total & $36.7 \%$ & $53.3 \%$ & $10.0 \%$ \\
\cline { 2 - 5 } & Males & $31.1 \%$ & $42.2 \%$ & $19.4 \%$ \\
\cline { 2 - 5 } $\begin{array}{l}\text { 4. How worried are you being } \\
\text { a victim of a sexual }\end{array}$ Fssault/attack by a stranger? & Total & $71.1 \%$ & $26.7 \%$ & $42.2 \%$ \\
\cline { 2 - 5 } & Males & $47.8 \%$ & $26.7 \%$ & $2.2 \%$ \\
\cline { 2 - 5 } & Females & $57.8 \%$ & $35.6 \%$ & $6.7 \%$ \\
\cline { 2 - 5 } & Total & $52.8 \%$ & $25.6 \%$ & $21.7 \%$ \\
\hline
\end{tabular}

Table: 3

Safety Level

\begin{tabular}{|l|l|c|c|c|c|}
\hline \multicolumn{2}{|c|}{} & $\begin{array}{c}\text { Very } \\
\text { Unsafe }\end{array}$ & Unsafe & Safe & Very Safe \\
\hline $\begin{array}{l}\text { 1. How safe do you feel } \\
\text { when alone, outside your } \\
\text { home after dark? }\end{array}$ & Males & $5.6 \%$ & $38.9 \%$ & $35.6 \%$ & $20.0 \%$ \\
\cline { 2 - 6 } & Females & $30.0 \%$ & $36.7 \%$ & $23.3 \%$ & $10.0 \%$ \\
\cline { 2 - 6 } $\begin{array}{l}\text { 2. How safe do you feel } \\
\text { when in a group outside } \\
\text { your home after dark? }\end{array}$ & Total & $17.8 \%$ & $37.8 \%$ & $29.4 \%$ & $15.0 \%$ \\
\cline { 2 - 6 } & Females & $4.4 \%$ & $22.2 \%$ & $63.3 \%$ & $10.0 \%$ \\
\cline { 2 - 6 } & Total & $36.7 \%$ & $33.3 \%$ & $25.6 \%$ & $4.4 \%$ \\
\hline
\end{tabular}


Table: 4

Precautionary measures

\begin{tabular}{|l|l|c|c|c|}
\hline \multicolumn{2}{|c|}{} & Always & Sometimes & Never \\
\hline \multirow{2}{*}{$\begin{array}{l}\text { 1. How often do you avoid } \\
\text { taking public transport after } \\
\text { dark? }\end{array}$} & Males & $25.6 \%$ & $60.0 \%$ & $14.4 \%$ \\
\cline { 2 - 5 } & Females & $73.3 \%$ & $21.1 \%$ & $5.6 \%$ \\
\cline { 2 - 5 } 2. How often do you keep in \\
$\begin{array}{l}\text { touch with family/friends to } \\
\text { inform them about your location } \\
\text { (or taxi registration number)? }\end{array}$ & Males & $49.4 \%$ & $40.6 \%$ & $10.0 \%$ \\
\cline { 2 - 5 } & Females & $73.3 \%$ & $53.3 \%$ & $16.7 \%$ \\
\cline { 2 - 5 } & & $51.7 \%$ & $34.4 \%$ & $11.1 \%$ \\
\hline
\end{tabular}

\section{Discussion}

It was hypothesized that female students will express a greater fear of crime and it holds true as in this study, there was a significant difference in the responses of males and females where females were more worried about being a victim of a crime than males. The statistics show that $50 \%$ of the females were "very worried" in comparison to $43.3 \%$ of the males. These results are similar to a previous research on college students where females had significant overall fear of victimization than males (Truman, 2007).

In summary, out of the eighteen fear variables in the questionnaire, gender differences were statistically significant for eleven variables which included a crime in general, crime committed by a stranger, crime while waiting at the bus stop and also while using the public transport, verbal abuse and insults, sexual attack/assault and stalking by a stranger and also acquaintance and attack based on gender. This study also hypothesized that both the genders will fear different types of crimes. The main categories included physical, sexual and verbal assault, stalking, harassment related to use of public transport and gender based attacks. The sub categories involved crime committed by a stranger or acquaintance. Among the crimes mentioned above, females were more fearful than men in nine variables which included a crime generally, crime committed by a stranger, crime while waiting at the bus stop and also while using the public transport, sexual attack/assault and stalking by a stranger and also acquaintance and attack based on gender. The results are similar to previous researches where females are more fearful of sexual assaults and harassment issues related to the use of public transport, fear attack based on gender (Hilinski, Neeson, Andrew, 2011) and avoid going out or travelling alone in public spaces after dark (Sur, 2012; Hille, 1999).

The fear of being victimized while waiting or using a public transport may arise due to overcrowded and cramped vans (Syam, Reeves \& Khan, 2011) in which women may face obscene remarks, unwanted gestures or touching. At rush hours, the waiting time at the wagon stop becomes unbearable as the passengers have to quickly climb on the 
wagons or else wait for another chance to catch a vacant seat. Seats cannot be reserved in the transport but for women, the front passenger seat is usually the only option. While using the public transport, females fear harassment where the vehicle driver pretends to change gear but instead takes advantage of the situation and touches the woman in the passenger seat or constantly looks in the rear view mirror to stare at the females sitting at the back. Sometimes, the drivers play loud or vulgar songs also making the women feel uncomfortable. It cannot be predicted when the routine groping may escalate into an extreme sexual assault. The emotive feeling of lack of support in a male dominated public space or control over what is happening in her surroundings due to her unequal status in the society tends to increase women's fears.

Although on one hand, it is true that not all men are the perpetrators of crime, the women in the patriarchal nature of the society often fear potential harm including sexual/physical and verbal attack due to their powerlessness in relation to other individuals in the hierarchical society. Michael Foucault's (1980) theory on power tells us that each individual has a power in relation to another individual. The males use this power to control the behaviour of individuals (women and children). According to Bartky (1988) these disciplinary practices subjugate women but they do not take power away from women. They generate skills and competencies that depend on maintenance of a stereotypical form of feminine identity. Women abide by the socio cultural norms of the society and do not travel at night alone or raise their voice against a crime because they are under social control. They have the power but they do not exhibit it due to the socio cultural norms therefore they feel powerless. In other words, according to Armstrong (2005), "disciplinary power fashions individuals who 'voluntarily' subject themselves to self-surveillance and self-normalization."

Pakistani society is an example of a collective society where family members have strong relations with each other and the individuals put family interest above personal interest. In this scenario, concepts of honour are of great importance. It is a matter of honour and shame for the female and her family where if a female becomes victim of a crime, then the authority and control of the males is questioned. Therefore, it is not only the sexual assault that the women fear as in this study the women are also fearful of harassment at bus stop and in public transport and stalking. With regards to gender based crimes, $71.1 \%$ of females responded that they felt 'very worried' about being a victim of a gender based attack in relation to only $31.1 \%$ male respondents.

Males were more fearful then females in only two variables which included verbal abuse and insults by a stranger and by an acquaintance. This may be due to the concepts of honour associated with males which hold high importance in the patriarchal setup of the society and fear verbal abuse which dishonours or challenges the identity of the males. In contrast, there is a high 'threshold of tolerance for women' Baxi (2001) due to which they 
tend to overlook crime or ignore crime. It is ironic that in Pakistan, the women cannot speak of physical assault, sexual abuse or harassment due to the fear of losing her and family's dignity. A woman's reputation is very fragile in the society and to avoid being victimized; they may feel that it is necessary to take precautions rather than facing crime due to their inability to deal with its consequences.

The women felt safe on only one safety variable which was 'being in a group outside home during the day'. Females in our society are usually escorted by male family members when there is work outside the boundaries of the private sphere. Thus, being alone on their own does not make them feel safe or protected and therefore they must accompany men. Women, if travelling alone, feel comfortable among other women as they can relate to the similar needs, experiences, interests and perspectives by virtue of being members of the same gender. Females may prefer to travel in women-only buses, vans or wagons, which are non-existent. The women prefer to be among the crowd or in groups because they feel powerless and are socialized into being submissive.

The second hypothesis for this study also yields similar results that the female students will be more likely to engage in precautionary behaviours as results show that $71.1 \%$ of the females "always" take precautionary behaviours to avoid being a victim of a crime in relation to only $12.2 \%$ of the males. A small percentage of women $(2.2 \%)$ stated that they "never" take precautionary measures. For a better and thorough understanding of the reasons behind some women taking precautions and others not taking it, further research studies, qualitative in nature, should be conducted.

Out of the ten precautionary behaviours listed, there were significant differences in the responses of males and females in six variables. The females 'always' observed these six precautionary behaviours like they avoid going out unaccompanied or after dark, avoid taking public transport or classes after dark, make transport arrangements prior to travelling and kept in touch with family/friends to tell them of location. The research on gendered fear of crime conducted in the west has also revealed that women possess pocket knife or pepper spray to feel protected from a crime (Runyan, et. al. 2007) but in our study both the males and females stated they 'never' carry a personal arm (knife, gun or pepper spray) to defend themselves in an attack.

The research also explored whether the respondents were more fearful of crimes committed by strangers or acquaintances. The results showed that the respondents were more fearful about being a victim of crime committed by acquaintance than for a crime committed by a stranger. Also, the males were more fearful about being victim of crimes committed by both strangers and acquaintances than females. A research by Scott (2003) contradicts these findings by stating that it is the women and not men that associate more danger with strangers. Even for some other fear variables, the responses of males and 
females were similar. It may be the case that the females tend to overlook or ignore the effect of crime by considering it as routine or normal behaviour. These crimes include eve-teasing and street harassment in which the women usually do not want to scream or raise their voice and get people's attention in cases like these. Women may have developed a "threshold of tolerance," Baxi (2001) which restricts them to report a crime and thus silently face the consequences.

In Pakistani society, the socio-cultural norms reinforce the traditional gender roles which tend to restrict the mobility of females. In our study, the girl students may have less fear of the strangers than the males because of a fixed daily routine they follow. There is not much chance of interaction with strangers if females have same routes or places to go to whereas for males, their freedom to roam around more freely and at various times of the day (e.g. night) than females allows more chances for their interaction with strangers. In traditional families and patriarchal structure of the Pakistani society, the children are socialized to learn the roles of a dominant father and submissive mother. Men and women have to accept the stereotypical roles assigned to respective gender as member of the society. This socialization process is a continuous process starting from family, educational institutions, media and religion. The girls are labelled as "good" if they abide by the rules and control their behaviour, failing which they can be considered as having a bad repute. Madriz (1997) states that the girls are told that if they do not follow the norms, something bad could happen to them and these "bad girls" will get what they deserve. The masculine fearless attitude and feminine fearful characteristic narrates how women tend to report higher score for fear of crime than men. Similarly, women are risk managers and indulge into precautionary behaviours rather than taking the risk of being exposed to a crime. Furthermore, males who engage in risky lifestyle behaviours are more often likely to feel safe (Truman, 2007). Hence the fear that males have for being a victim of crime committed by stranger may be more than females owing to their freedom of mobility and also risk-taking attitude.

\section{Limitations}

1. Past experiences of being victimized is an important predictor of fear of crime and precautionary behaviour but it was not dealt with in this research study.

2. An individuals' age, class, income level, family structure and may influence his/her fear of crime level but for this study the focus was only on gender and data for the other variables was not collected.

\section{Recommendations}

1. Further studies should be conducted to account for confounding variables in this study e.g. crime rate of the area and income level/social class of the respondents. 
2. Gender sensitization sessions should be organized at different levels like educational institutes, workplaces and communities to highlight the fears faced by respective genders due to the socio-cultural norms of the society.

\section{References}

Armstrong, A. (2005). Michel Foucault: Feminism: The Internet Encyclopaedia of Philosophy, ISSN 2161-0002, http://www.iep.utm.edu/foucfem.

Bartky, S. Foucault (1988). Femininity and the Modernization of Patriarchal Power, I. Diamond \& L. Quinby (eds), Feminism and Foucault: Reflections on Resistance, Boston: Northeastern University Press.

Baxi, P. (2001). Sexual Harassment, Towards Equality: A Symposium on Women, Feminism and Women's Movements. New Delhi: Singh.

Chan, Wendy \& George, Rigakos (2002). Risk, Crime and Gender, British Journal of Criminology, vol.42:4, pp.743-761.

Dolezal, Dalibor (2009). Understanding the Fear of Crime, Croatian Journal of Rehabilitation Research, vol.45:2, p.55

Foucault, M. (1980). Power/ Knowledge: Selected Interviews and Other Writings, 19721977. Pantheon.

Fountain, M. Bracknell Forest Council (2012). Fear of Crime Survey, http://www.bracknell-forest.gov.uk/fear-of-crime-survey-2012.pdf.

Grasmick, H.G., Hagan, J., Blackwell, B.S. \& Arneklev, B. J. (1996). Risk Preferences and Patriarchy: Extending Power Control Theory, Social Forces, vol.75, pp.177199.

Hagan, J., Simpson, J. \& Gillis, A. R. (1987). Class in the Household: A Power-Control Theory of Gender and Delinquency. American Journal of Sociology, vol.92:4, pp.788-816, http://www.jstor.org/stable/2780039

Haggerty, K. (2003). From Risk to Precaution: The Rationalities of Crime Prevention, Risk and Morality, pp.193-214.

Hale, C. (1996). Fear of Crime: A Review of the Literature. International Review of Victimology, vol.4, pp.79-150. 
Hilinski, C. M., Pentecost Neeson, K. E. \& Andrews, H. (2011). Explaining the Fear of Crime among College Women, in their Own Words. The Southwest Journal of Criminal Justice, vol.8:1, pp.112-127.

Hille, K. (1999). Gendered Exclusions: Women's Fear of Violence and Changing Relations to Space. Geografiska Annaler: Series B, Human Geography, 81: 111124. doi: 10.1111/j.0435-3684.1999.00052.x

Hunt, A. (1999). Anxiety and Social Explanation: Some Anxieties about Anxiety. Journal of Social History, vol.32:3, pp.509-528.

Madriz, E. (1997). Nothing bad Happens to Good Girls: Fear of Crime in Women's Lives, California: University of California Press, p.116.

May, D. C., Herbert, J., Cline, K. \& Nellis, A. (2011). Predictors of Fear and Risk of Terrorism in a Rural State. International Journal of Rural Criminology, vol.1:1.

Oxford English Dictionary (2013). http://www.oxforddictionaries.com/definition/english/ crime

Rader, N. E. (2004). The Threat of Victimization: A Theoretical Reconceptualization of Fear of Crime. Sociological Spectrum, vol.24:6, pp.689-704.

Renzetti, C. M., Miller, S. L. \& Gover, A. R. (2012). Routledge International Handbook of Crime and Gender Studies, Routledge, p.65.

Runyan, C. W., Casteel, C., Moracco, K. E. \& Coyne-Beasley, T. (2007). US Women's Choices of Strategies to Protect Themselves from Violence. Injury Prevention, vol.13:4, pp.270-275.

Scarborough Borough Council, (2007). Fear of Crime Survey, http://www.scarborough.gov.uk/ pdf/Fear of Crime Survey 2007.pdf

Scott, H. (2003). Stranger Danger: Explaining Women's Fear of Crime. Western Criminology Review, vol.4:3, pp.203-214.

Smith, W. R. \& Torstensson, M. (1997). Gender Differences in Risk Perception and Neutralizing Fear of Crime: Toward Resolving the Paradoxes. British Journal of Criminology, vol.37:4, pp.608-634. 
Sur, P. (2012). Fear of Crime and Victimization: Retracing Women's Risk Perceptions in Private Spaces in the Urban City of Kolkata. Journal of International Women's Studies, vol.13:1.

Syam, A. A., Reeves, D. \& Khan, A. (2011). The Effects of Cultural Dimension on People's Perception about Security on Public Transport. In A. Pratelli (Ed.), Urban Transport XVII Urban Transport and the Environment in the 21st Century, vol.16. WIT Press.

Truman, J. L. (2007). Fear of Crime and Perceived Risk of Victimization among College Students. (Unpublished master's thesis).

UN-HABITAT (2000). The Global Assessment on Women's Safety, ttp://www.unhabitat.org/downloads/docs/7380_832_AssesmentFinal.pdf

Van Brunschot, E. G., Laurendeau, J. \& Anne Keown, L. (2009). The Global and the Local: Precautionary Behaviours in the Realms of Crime, Health, and Home Safety. Canadian Journal of Sociology, vol.34:2, pp.403-430.

Warr, M. (2000). Fear of Crime in the United States: Avenues for Research and Policy. Measurement and Analysis of Crime and Justice, vol.4, pp.451-489, https://www.ncjrs.gov/criminal_justice2000/vol_4/04i.pdf

Welchman, L. \& Hossain, S. (2007). Honor: Crimes, Paradigms and Violence against Women. (2 ed.). New York: Zed books Ltd.

White, H. (1986). Damsels in Distress: Dependency Themes in Fiction for Children and Adolescents. Adolescence, vol.21:82, pp.251-256

Zhou, S., Yan, Y. \& Cooley, S. (2011). Damsel in Distress: Dramatization and Sensationalism in American Kidnapping Stories. China Media Report Overseas, vol.71, pp.55-66

Ms. TaskeenMansoor is an Adjunct Faculty, Department of Gender Studies, Fatima Jinnah Women University, Rawalpindi

Dr. Rukhsana Hasan is Chairperson in the Department of Gender Studies, Fatima Jinnah Women University, Rawalpindi 